\title{
Expression of Growth-Associated Protein B-50 (GAP43) in Dorsal Root Ganglia and Sciatic Nerve During Regenerative Sprouting
}

\author{
Catharina E. E. M. Van der Zee, Henk B. Nielander, Jan P. Vos, Sofia Lopes da Silva, Joost Verhaagen, A. \\ Beate Oestreicher, Louise H. Schrama, Peter Schotman, and Willem Hendrik Gispen \\ Division of Molecular Neurobiology, Rudolf Magnus Institute and Institute of Molecular Biology and Medical Biotechnology, \\ Laboratory for Physiological Chemistry, University of Utrecht, Padualaan 8, $3584 \mathrm{CH}$ Utrecht, The Netherlands
}

Recently it has been shown that B-50 is identical to the neuron-specific, growth-associated protein GAP43. The present study reports on the fate of B-50/GAP43 mRNA and B-50/GAP43 protein, determined by radioimmunoassay, in a rat model of peripheral nerve regeneration (sciatic nerve crush) over a period of 37 and 312 d, respectively. Moreover, the effects of repeated subcutaneous injection of the neurotrophic peptide Org.2766 (an ACTH4-9 analog) and of a conditioning lesion on B-50/GAP43 protein levels in the regenerating nerve and dorsal root ganglia (DRG) were investigated. Both treatments enhanced the functional recovery as evidenced by a foot-flick withdrawal test. Immunocytochemical analysis using antineurofilament antibodies revealed a peptide-induced increase in the number of outgrowing sprouts in the sciatic nerve. Both the peptide and the conditioning lesion amplified the crush lesion-induced increase in B-50 protein content in the nerve as determined by radioimmunoassay. $B-50$ protein levels seem to correlate proportionally with the number of sprouts.

In the DRG of the crushed sciatic nerve, the time course of B-50 expression was studied. B-50 mRNA was quantified from Northern blots. A linear increase up to 10 times the basal level of B-50 mRNA was observed 2 d postsurgery, followed by a gradual decline to normal levels at day 37 . The first significant rise in B-50 mRNA level became apparent between 8 and $16 \mathrm{hr}$ after placement of the crush lesion. The first significant rise in B-50 protein level occurred $\mathbf{4 0} \mathrm{hr}$ after the crush lesion, reaching a plateau of 3 times the basal level between day 6 and 20. B-50 protein levels in DRG cell bodies remained elevated up to $60 \mathrm{~d}$ after crush, a period much longer than that observed for B-50 mRNA. Thus, during a later phase of peripheral axonal regeneration, the presence of B-50 appears to be prolonged, probably by an increase in half-life and not so much by enhanced transcription.

Treatment with Org.2766 did not affect the B-50/GAP43 levels in DRG cell bodies during the first $6 \mathrm{~d}$ following crush. Conditioning lesion resulted in a DRG B-50/GAP43 protein amount at the same level as in rats $14 \mathrm{~d}$ after the test lesion.

\footnotetext{
Received Aug. 18, 1988; revised Mar. 16, 1989; accepted Mar. 23, 1989.

The authors acknowledge Inge Hassink and Ed Kluis for preparing the figures, Ruud Bloemen and Mariolein van der Velde for their excellent technical assistance, and Lia Claessens for editing the manuscript. The research was supported in part by grants of the Prinses Beatrix Foundation and the Koningin Wilhelmina Foundation.

Correspondence should be addressed to Dr. W. H. Gispen at the above address. Copyright (c) 1989 Society for Neuroscience $0270-6474 / 89 / 103505-08 \$ 02.00 / 0$
}

B-50/GAP43 levels in DRG are probably influenced by the rapid axonal transport of the protein, as has been reported by others.

The neuron-specific phosphoprotein B-50 (MW 23.5 kDa, IEP $4.5)$ belongs to a family of growth-associated proteins (GAPs) and is identical to GAP43, GAP48, F1, and pp46 (Gispen et al., 1986; Jacobson et al., 1986; Perrone-Bizzozero et al., 1986; Meiri et al., 1986; Pfenninger, 1986; Zwiers et al., 1987; Karns et al., 1987; Basi et al., 1987; Rosenthal et al., 1987; Neve et al., 1987; Nielander et al., 1987). Recently, it became evident that B-50 is also identical to P57, a calmodulin-binding protein in the nervous system (Cimler et al., 1987). A role of this protein in axonal growth has been suggested because B-50, like pp46 (Pfenninger, 1986), is a major constituent of the axonal growth cone (De Graan et al., 1985; Katz et al., 1985; Meiri et al., 1986; Skene et al., 1986; Van Hooff et al., 1988), and it is present in outgrowing neurites in fetal and neonatal rat brain and spinal cord (Jacobson et al., 1986; Oestreicher and Gispen, 1986; Gorgels et al., 1987) and in outgrowing processes of NGF-differentiated PC12 cells (Van Hooff et al., 1986; Basi et al., 1987). The GAPs, like B-50, have been implicated in axonal repair processes as well (Skene and Willard 1981; Benowitz et al., 1981; Benowitz and Lewis, 1983). The protein is expressed in regenerating axons following mechanical damage of the sciatic nerve in the rat (Verhaagen et al., 1986) and is present in the presynaptic terminal of newly formed neuromuscular junctions (Verhaagen et al., 1988).

Previously, it was shown that axonal regeneration in the crushed sciatic nerve can be facilitated by either the placement of an earlier "conditioning" lesion (McQuarrie and Grafstein, 1973; McQuarrie et al., 1977; McQuarrie, 1978) or by treatment with neurotrophic agents, such as melanocortins (Strand and Kung, 1980; Gispen et al., 1987). Posttranslational products of pro-opiomelanocortin, such as ACTH and MSH peptides, enhance postlesion repair by increasing the number of outgrowing myelinated and unmyelinated newly formed axons (Bijlsma et al., 1983; Verhaagen et al., 1987). The mechanism by which either melanocortins or conditioning lesion enhance the recovery of nerve function is still largely unknown.

The aim of the present study was to determine the time course of the expression and fate of B-50/GAP43 following a crush lesion of the rat sciatic nerve, in terms of B-50 mRNA and B-50 protein levels in dorsal root ganglia (DRG) and B-50 protein levels in the sciatic nerve. Furthermore, the effect of enhancement of nerve repair by means of a conditioning lesion or peptide treatment on B-50 protein levels was studied. 


\section{Materials and Methods}

Animals and surgical procedure. Female rats of an inbred Wistar strain (TNO, Zeist, NL), body weight 130-200 gm, were subjected to a unilateral crush lesion of the sciatic nerve, as described in detail by De Koning et al. (1986). The crush lesion, or "test" lesion, was placed 7 $\mathrm{mm}$ distal from the point where the sciatic nerve emerged from under the gluteus maximus muscle. The crush lesion was performed under Hypnorm anesthesia (Duphar, Weesp, NL; $0.8 \mathrm{ml} / \mathrm{kg}$ body weight). The distal border of the $2.0-\mathrm{mm}$ wide crush lesion was marked with an epineural suture (Ethicon 6.0) in the peroneal branch of the sciatic nerve to locate the position of the crush.

One group of rats was crushed twice, with an interval of 2 weeks (McQuarrie, et al., 1978; Dekker, 1987). The "conditioning" lesion was placed $10 \mathrm{~mm}$ distal to the normal crush sitc $14 \mathrm{~d}$ beforc the test lesion was performed.

Return of sensorimotor function. The sensitivity to noxious stimulation was assessed by means of a reflex withdrawal test employing a small electric current applied locally to the foot sole (for details, see De Koning et al., 1986). In short, the rat was immobilized, and 2 stimulation poles were placed at different points on the skin of the foot sole. A rat withdraws its paw immediately when the skin of the foot sole closes the electrical circuit between the stimulation poles. Starting on postoperation day 14 , the animals were tested daily, and the number with a positive foot withdrawal reflex at the $0.1 \mathrm{~mA}$ stimulus was scored. Data were analyzed using a $\chi^{2}$ test.

Peptide administration. The peptide Org.2766 [ACTH4-9 analog H-Met $\left(\mathrm{O}_{2}\right)$-Glu-His-Phe-D-Lys-Phe-OH] was a gift from Organon Int. BV (Oss, NL). Org. 2766 was dissolved in $0.1 \%(\mathrm{wt} / \mathrm{vol}) \mathrm{BSA} / 0.05 \mathrm{~N}$ $\mathrm{HCl}$ and subsequently diluted with $0.9 \%$ (wt/vol) $\mathrm{NaCl}$ solution to a final concentration of $7.5 \mu \mathrm{g} / \mathrm{kg} / 0.5 \mathrm{ml}$ solution (with a neutral $\mathrm{pH}$ ) and administered s.c. every $48 \mathrm{hr}$, with the first injection immediately after the crush lesion operation. The control rats received the saline solution with the same concentration of BSA.

Dissection. After decapitation, the crushed nerves were dissected distally from the epineural suture on and cut in 5 - $\mathrm{mm}$ nerve pieces over a length of $20 \mathrm{~mm}$, or one $10-\mathrm{mm}$ piece was taken. The nerves of noncrushed rats were also dissected and cut in $5-\mathrm{mm}$ or $10-\mathrm{mm}$ pieces. DRG $\left(\mathrm{L}_{4} \mathrm{~L}_{5} \mathrm{~L}_{6}\right)$ from the crushed side of the rat and DRG from noncrushed rats were also dissected.

Immunohistochemistry and quantification of sprouts. At 2, 3, and 4 $\mathrm{d}$ after sciatic nerve crush, rats were decapitated, and crushed sciatic nerves were removed and processed for immunohistochemistry as described by Verhaagen et al. (1987). In short, the nerves were fixed in periodate-lysine-paraformaldehyde in $50 \mathrm{~mm}$ phosphate buffer (McLean and Nakane, 1977) and cryoprotected in graded sucrose solutions up to a concentration of $35 \%$. Four $-\mu \mathrm{m}$ thick transverse cryosections at the distal border of the crush, marked by the epineural suture, were incubated with affinity-purified anti-150 kD neurofilament protein IgGis for $24 \mathrm{hr}$ (Verhaagen et al., 1987, see illustration). The site of antigenantibody binding was visualized with swine anti-rabbit IgGs conjugated to FITC (1:100; Dako, Denmark). For each section, sprouts were counted in 3 color slides representing a total of $0.1 \mathrm{~mm}^{2}$ of the tibial nerve area. The tibial nerve area was circumscribed using a microscope (Olympus $\mathrm{BH}-2$ ) with a drawing tube attachment. Subsequently, the area of the circumscribed fascicle was measured with a graphics tablet coupled to an IBM microcomputer. The total number of sprouts in each section was calculated from the $0.1 \mathrm{~mm}^{2}$ count and the total tibial nerve area. The person counting the sprouts was unaware of the treatment the rat had received. Data were analyzed for statistical significance with an $F$ test, followed by a supplemental Student's $t$ test.

$B-50$ radioimmunoassay. In order to measure the amount of $\mathrm{B}-50$ protein in a radioimmunoassay (RIA), the 5 - or $10-\mathrm{mm}$ nerve pieces and the DRG $\left(\mathrm{L}_{4} \mathrm{~L}_{5} \mathrm{~L}_{6}\right)$ were homogenized in $1.0 \%(\mathrm{wt} / \mathrm{vol})$ sodium dodecyl sulfate (SDS) $(90 \mu \mathrm{l} / \mathrm{mg}$ tissue wet weight), heated for $5 \mathrm{~min}$ at $100^{\circ} \mathrm{C}$. The RIA was performed essentially as described by Oestreicher et al. (1986). A B-50 tracer was prepared with high specific activity (10$30 \mu \mathrm{Ci} / \mu \mathrm{g}$ protein) by phosphorylation for $30 \mathrm{~min}$ at $30^{\circ} \mathrm{C}$ of $1-2 \mu \mathrm{g}$ purified B-50 protein (Oestreicher et al., 1983) with carrier-free $\gamma^{-32} \mathrm{P}$ ATP $(500 \mu \mathrm{Ci}$, S.A. $3000 \mathrm{Ci} / \mathrm{mmol}$ purchased from Amersham $)$ catalyzed by $0.48 \mu \mathrm{g}$ purified protein kinase $C$. (Aloyo et al., 1983) in the presence of $16 \mu \mathrm{g}$ phosphatidylserine, $2 \%$ glycerol, $10 \mathrm{mM} \mathrm{MgCl}, 0.15$ $\mathrm{mM} \mathrm{CaCl}_{2}, 10 \mathrm{~mm}$ Tris- $\mathrm{HCl}$ at $\mathrm{pH} 7.4$ in a final volume of $80 \mu \mathrm{l}$. The reaction was terminated by addition of $40 \mu$ l denaturing solution containing SDS (Oestreicher et al., 1986). The tracer was purified by SDS gel electrophoresis on a $0.5 \mathrm{~mm} 11 \%(\mathrm{wt} / \mathrm{vol})$ polyacrylamide gel and monitored by Cerenkov counting. After staining of the gel for proteins with fast green, the highly labeled B-50 band was excised. The radiolabeled B-50 was extracted from the gel by means of an ISCO Electrophoretic Concentrator (ISCO Inc., Lincoln, Nebraska). The acidic excised gel piece was neutralized by rinsing with electrophoresis buffer EBIM [comprising EB, $0.77 \mathrm{~m}$ glycine and $0.1 \mathrm{~m}$ Tris, and a protease inhibitor mix (IM)]. This IM consisted of $5 \mathrm{mM}$ phenylmethylsulfonylchloride, $0.15 \mathrm{M} \mathrm{NaN}_{3}, 50 \mathrm{~mm} \mathrm{NaF}, 1 \mathrm{~mm}$ EGTA, and $1000 \mathrm{KIE}$ Trasylol (Bayer, Leverkussen, BDR) at pH 7.4 in a volume of $20 \mathrm{ml}$. One $\mathrm{ml} \mathrm{IM}$ was routinely added to $50 \mathrm{ml} \mathrm{EB}$, constituting EBIM. Thereafter, the labeled B-50 gel piece was homogenized in $1 \mathrm{ml}$ EBIM. The homogenate was placed in a sterile sample cup of the concentration cell filled with sterile EBIM and transferred to the small cup at the anode for $2 \mathrm{hr}$, using $3 \mathrm{~W}$. The purified tracer was analyzed by SDS-PAGE, aliquoted and stored at $-20^{\circ} \mathrm{C}$.

The RIA was performed in $400 \mu \mathrm{l}$ detergent containing medium A [200 $\mathrm{mm} \mathrm{NaCl}, 10 \mathrm{~mm}$ EDTA, $10 \mathrm{~mm} \mathrm{NaH}_{2} \mathrm{PO}_{4}, 0.5 \%$ (wt/vol) Nonidet$\mathrm{P} 40,0.1 \%(\mathrm{wt} / \mathrm{vol}) \mathrm{SDS}$ at $\mathrm{pH} 7.2]$ using affinity-purified anti-B-50 immunoglobulins (antisera 8420 and 8613) and purified B-50 as a standard. The detection range was $0.1-10 \mathrm{ng} \mathrm{B-50}$. As a control, different amounts of homogenates from rat liver and lung were assayed as well. No B-50 immunoreactivity was detected. Moreover, using the anti-B50 immunoglobulins on Western blots from nervous tissue, heart, lung, liver, and kidney, B-50 was detected only in nervous tissue.

Homogenate total protein concentrations were measured using the method of Lowry et al. (1951).

Data were analyzed for statistical significance with an $F$-test, followed by a supplemental Student's $t$ test.

Northern blot analysis of $B-50 \mathrm{mRNA}$. Total RNA was isolated essentially according to the method of Chirgwin et al. (1979) as modified by Nielander et al. (1987). DRG $\left(\mathrm{L}_{4} \mathrm{~L}_{5} \mathrm{~L}_{6}\right)$ were immediately frozen in liquid $\mathrm{N}_{2}$ and subsequently homogenized in $1.0 \mathrm{ml}$ of a solution containing $6 \mathrm{~m}$ guanidinium isothiocyanate (GITC), $0.5 \%$ (wt/vol) sodium $N$-laurylsarcosinate, $0.1 \%(\mathrm{wt} / \mathrm{vol})$ antifoam (Sigma), $0.5 \%(\mathrm{wt} / \mathrm{vol})$ $\beta$-mercaptoethanol, and $0.05 \mathrm{M}$ sodium citrate, $\mathrm{pH} 7.0$, at room temperature in a glass tube with a tightly fitting Teflon pestle (Potter-Elvehjem) with 10 strokes up and down. The homogenate was layered on a cushion of $1.0 \mathrm{ml}$ of $5.7 \mathrm{M}$ cesium chloride and $0.1 \mathrm{M}$ EDTA, $\mathrm{pH} 7.0$ (Glisin et al., 1974). RNA was pelleted by centrifugation at 436,000 $g_{\max }$ for $3 \mathrm{hr}$ at $20^{\circ} \mathrm{C}$, using a fixed angle rotor in a Beckman TL- 100 centrifuge. The RNA pellet was redissolved in $25 \mathrm{~mm}$ EDTA, pH 7.0, and precipitated by ethanol.

Analysis of B-50 mRNA expression was carried out by size fractionation of $3.0 \mu$ g glyoxylated (McMaster and Carmichael, 1977) total RNA on $1.0 \%(\mathrm{wt} / \mathrm{vol})$ agarose gels formed in $10 \mathrm{~mm}$ sodium phosphate, $\mathrm{pH}$ 7.0, followed by capillary blotting to nylon transfer membranes (Hybond N, Amersham, UK; Maniatis et al., 1982). Filter hybridizations were performed in the presence of formamide $(50 \%$, vol $/ \mathrm{vol})$ and polyethylene glycol $(10 \%, \mathrm{vol} / \mathrm{vol})$ (Amasino, 1986), essentially as described by DeLeon et al. (1983). RNA probe synthesis was carried out by in vitro transcription on Hind III linearized plasmid with a B-50 cDNA sequence as insert (Nielander et al., 1987) with $\mathrm{T}_{7}$ RNA polymerase (Promega Biotec) and $\alpha^{-32}$ P-CTP (Amersham, UK; $800 \mathrm{Ci} / \mathrm{mmol}$ ) to give a specific activity of about $10^{9} \mathrm{dpm} / \mu \mathrm{g}$. Hybridization temperature was $55^{\circ} \mathrm{C}$, the final wash was carried out in $0.1 \times \mathrm{SSC}, 0.1 \%(\mathrm{wt} / \mathrm{vol}) \mathrm{SDS}$ (SSC: $0.15 \mathrm{~m}$ sodium chloride, $0.015 \mathrm{~m}$ sodium citratc) at $65^{\circ} \mathrm{C}$. After washing, the filters were exposed to preflashed Fuji-RX film with intensifying screens at $-80^{\circ} \mathrm{C}$.

Quantification of $B-50 \mathrm{mRNA}$. Similar amounts of total RNA $\left(\mathrm{A}_{260}\right)$ $A_{280}>2.0$ ), as measured by $A_{260}-A_{320}$ from the ganglia of rats at different time periods following the crush lesion, were applied to one gel $(0,1$, $2,4,6,14,20$, and $37 \mathrm{~d})$ and a subsequent gel $(0,0.5,4,8,16,24$, and $32 \mathrm{hr}$ ). In this way, Northern blotting and probing of one series of time points were performed under the same conditions. Two overlapping time points were chosen to fit both series into one time curve. After probing with the B-50 cRNA, the filters were stripped (the effectiveness was checked by autoradiography) and reprobed with a rat glyceraldehyde-3-phosphate dehydrogenase (GAPDH) cDNA probe as a control. Random-primed labeling (Boehringer, Mannheim) with $\alpha{ }^{32} \mathrm{P}-\mathrm{dCTP}$, a hybridization temperature of $42^{\circ} \mathrm{C}$, and a final wash at $50^{\circ} \mathrm{C}$ were applied. For quantification of hybridization intensities, autoradiographs were examined by computer-assisted densitometry and image analysis (TIM program, TEA, DIFA BV). In a control experiment, a concentration range of $0.1-2.0 \mathrm{ng}$ of purified B-50 cRNA, quantified similarly, 


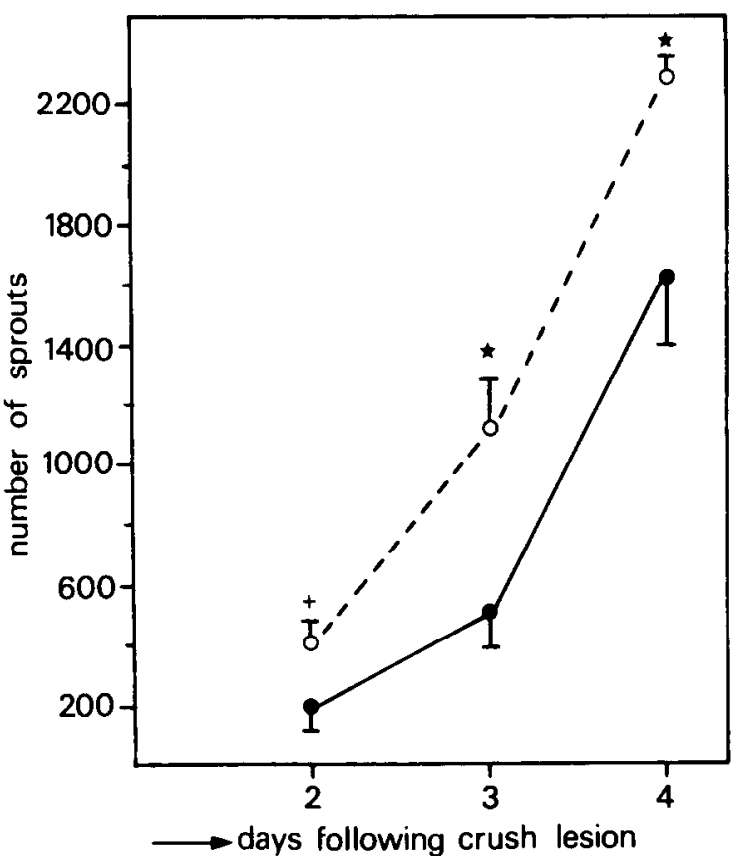

Figure 1. Effect of Org.2766 on the number of sprouts in the tibial nerve at the distal border of the crush site. Following crush lesion, newly outgrowing sprouts were identified by antineurofilament $150 \mathrm{kDa}$ antibodies, and the numbers of sprouts were counted in $0.1 \mathrm{~mm}^{2}$ crosssections. Rats were injected with saline (๑) or Org.2766 (7.5 $\mu \mathrm{g} / \mathrm{kg} \mathrm{s.c./}$ $48 \mathrm{hr})(\mathrm{O})$, starting immediately following the crush lesion. A significant increase in the number of regenerating nerve fibers following treatment with Org.2766 was observed compared to saline treatment $\left(^{+} p<0.1\right.$, ${ }^{*} p<0.05$, Student's $t$ test).

resulted in a linear relationship between integrated total density of the hybridization bands above background and the amount of cRNA applied to the gel.

The B-50 mRNA values were corrected for GAPDH mRNA amounts in the same lanes and expressed relative to the values in DRG of noncrushed rats $(100 \%)$. Each time point was determined as the mean of two independent values obtained from the ganglia of 2 rats. The correction for the same amount of GAPDH mRNA did not change the time curves of B-50 mRNA levels substantially.

\section{Results}

Recovery of sensorimotor function following sciatic nerve crush Recovery of sensorimotor function following the crush lesion, tested in the foot reflex withdrawal test, starts after day 15 (Table 1). Treatment with Org. $2766(7.5 \mu \mathrm{g} / \mathrm{kg}$ s.c. $/ 48 \mathrm{hr})$, an ACTH4-9 analog, showed an accelerated recovery of function (Table $1 \mathrm{~A}$ ). At day 17 postsurgery, only 1 of 10 saline-treated rats displayed reflex withdrawal of the paw to the noxious foot sole stimulation, whereas in the peptide-treated group, 8 of 10 rats responded to the $0.1 \mathrm{~mA}$ current stimulus ( $\chi^{2}$ test, $p<0.005$ ).

A conditioning crush lesion, placed distally 2 weeks before the test lesion, accelerated the recovery of function as well (Table $1 B$ ). At postlesion day 17,2 of 10 rats bearing the test lesion only showed a positive foot withdrawal reflex, whereas 8 of 9 rats receiving a conditioning lesion as well responded to the noxious stimulation $\left(\chi^{2}\right.$ test, $\left.p<0.01\right)$.

\section{Number of sprouts in the tibial nerve following nerve crush}

The outgrowth of regenerating nerve fibers was studied at 2, 3, and $4 \mathrm{~d}$ after a crush lesion in saline- or Org. $2766(7.5 \mu \mathrm{g} / \mathrm{kg}$ s.c. $/ 48 \mathrm{hr}$ )-treated rats. At the distal border of the lesion, the

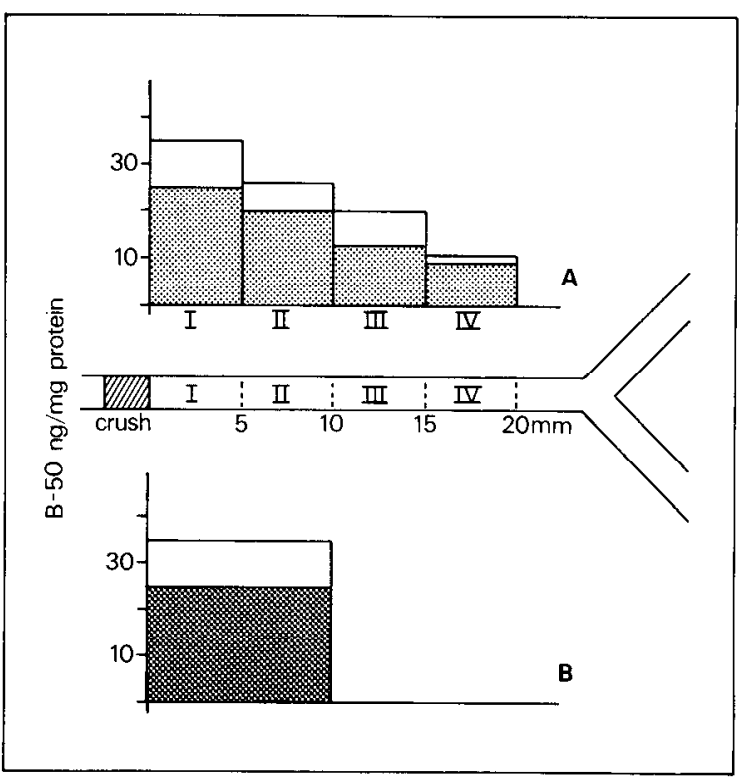

Figure 2. Increase of B-50 protein levels in the sciatic nerve at day 6 following crush lesion. Effect of Org. 2766 treatment $(A)$ or conditioning lesion $(B)$. The B-50 protein amount in control noncrushed rat sciatic nerve is in the range of 10.6 to $12.4 \mathrm{ng} / \mathrm{mg}$ protein $(n=10)$. $A$, The increase in B-50 protein level in rats injected with Org.2766 $(7.5 \mu \mathrm{g} / \mathrm{kg}$ s.c. $/ 48 \mathrm{hr})(\square)$, starting immediately after the crush lesion, was significantly different from the increase in rats injected with saline (四). Analysis of variance, $\mathrm{F}(1,8)=5.14, p<0.05$. $B$, The increased $\mathrm{B}-50$ protein level in rats receiving a conditioning lesion 2 weeks before the test lesion ( $\square$ ) was significantly different from the increased B-50 level in rats receiving the test lesion only (田) (Student's $t$ test, $p<0.05$ ).

small regenerating sprouts, identified by antineurofilament 150 $\mathrm{kD}$ antibodies, were counted in $0.1 \mathrm{~mm}^{2}$ cross-sections of the tibial nerve, and the total number per cross-section was calculated. As shown in Figure 1, Org.2766 treatment increased the number of sprouts at the first time point of analysis $(2 \mathrm{~d}$ after crush). At postoperative days 3 and 4, peptide-treated rats showed a significant increase in the number of outgrowing sprouts as compared to saline-treated rats.

\section{$B-50$ protein content in sciatic nerve distal from the crush site}

At day 6 following a crush lesion, newly formed sprouts will have progressed into the distal nerve stump up to a distance of approximately $15 \mathrm{~mm}$ distal from the crush site [calculated from Table 1. Sensorimotor function following a crush lesion of the sciatic
nerve

\begin{tabular}{llllll} 
& $A$ & & & $B$ \\
\cline { 5 - 6 } Day & $\begin{array}{l}\text { Saline } \\
(n=10)\end{array}$ & $\begin{array}{l}\text { Org.2766 } \\
(n=10)\end{array}$ & & $\begin{array}{l}\text { Control } \\
(n=10)\end{array}$ & $\begin{array}{l}\text { Condition- } \\
\text { ing lesion } \\
(n=9)\end{array}$ \\
\hline 13 & 0 & 0 & 0 & 0 \\
15 & 0 & 4 & 0 & 4 \\
17 & 1 & $8^{* *}$ & 2 & $8^{*}$
\end{tabular}

Depicted is the number of rats showing a positive foot withdrawal reflex.

$A$, Rats were treated with saline or Org.2766 $(7.5 \mu \mathrm{g} / \mathrm{kg} \mathrm{s.c.} / 48 \mathrm{hr})$ starting immediately after the crush lesion.

$B$, Rats received a conditioning lesion 2 weeks before the test lesion or received the test lesion only $\left(\chi^{2}\right.$ test, $\left.{ }^{*} p<0.01,{ }^{* *} p<0.005\right)$. 


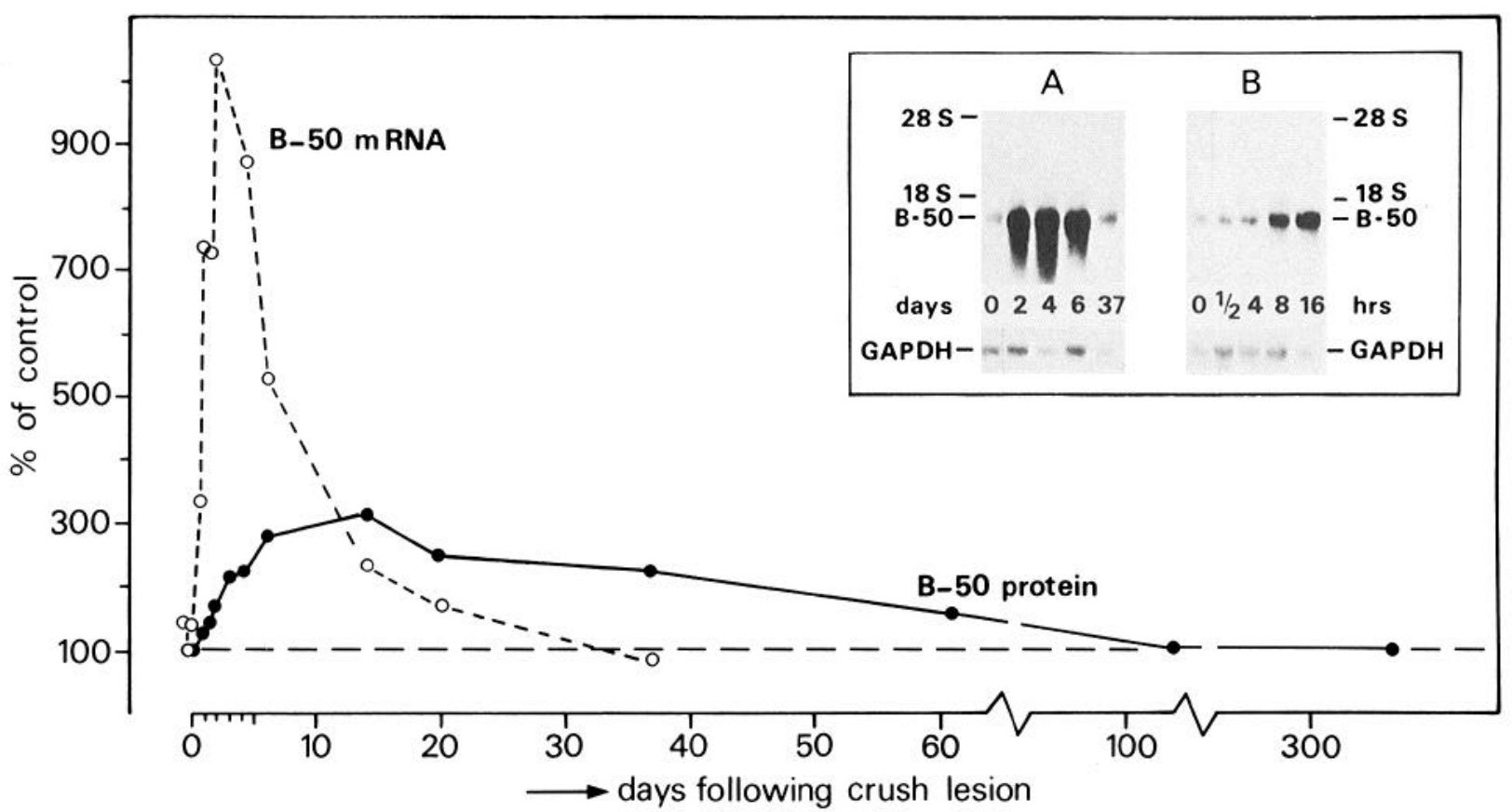

Figure 3. Expression of B-50 mRNA and B-50 protein in DRG following crush lesion of the sciatic nerve. The amount of B-50 mRNA and B-50 protein in DRG was expressed as percentage of noncrushed rats (100\%). At 0, 0.5, 4, 8, 16, 24, and $32 \mathrm{hr}$ and at 2, 4,6,14,20, and $37 \mathrm{~d}$ after crush, the B-50 mRNA was determined by means of a semiquantitative Northern blot analysis of total DRG RNA, obtained from the pooled ganglia $\left(\mathrm{L}_{4} \mathrm{~L}_{5} \mathrm{~L}_{6}\right)$ of 2 rats in duplicate. Inset, Lanes from the crucial time points $0,2,4,6$, and $37 \mathrm{~d}$ and $0,0.5,4,8$, and 16 hr. The positions of the 28 and $18 \mathrm{~S}$ rRNA of B-50 mRNA $(1.5 \mathrm{~kb})$ and GAPDH mRNA $(1.3 \mathrm{~kb})$ are indicated (inset). The increase in B-50 mRNA was significant at time points between $16 \mathrm{hr}$ and $20 \mathrm{~d}$ (Student's $t$ test, $p<0.05$ ). At 0,24 , and $40 \mathrm{hr}$ and at 2, 3, 4, 6, 14, 20, 37, 61, 104, and 312 d after crush, the B-50 protein amount was measured by means of RIA. Control level (=100\%) is $15 \mathrm{ng} / \mathrm{mg}$ protein. The increase in B-50 protein was significant at time points between $40 \mathrm{hr}$ and $61 \mathrm{~d}$ (Student's $t$ test, $p<0.05$ ).

data of Verhaagen et al. (1987) obtained under identical conditions]. At day 6 after a crush lesion, the distal portion of the nerve was dissected either over a length of $20 \mathrm{~mm}$ and cut into 5 -mm segments (Fig. $2 A$ ) or dissected over $10 \mathrm{~mm}$ (Fig. $2 B$ ). B-50 levels were determined using RIA. As shown in Figure $2 A$, Org. 2766 treatment increased the B-50 level in nerve segments I, II, and III as compared to saline treatment. Analysis of variance revealed that this increase in peptide-treated rats was significant in all 3 segments distal to the crush site (Fig. $2 A$ ) $(\mathrm{F}(1,8)=5.14, p<0.05)$. In saline-treated rats, the $\mathrm{B}-50$ protein content was significantly increased in nerve segments I and II as compared to noncrushed controls (basal levels of B-50 in nerves of control noncrushed rats were between 10.6 and 12.4 $\mathrm{ng} / \mathrm{mg}$ protein).

A conditioning lesion 2 weeks before the test lesion resulted, at postoperation day 6 , in an increase in B- 50 protein content in the first $10-\mathrm{mm}$ segment distal to the crush site as compared with rats that had received the test lesion only (Fig. $2 B$; Student's $t$ test, $p<0.05$ ). In the test lesion group, the B-50 protein level was significantly higher when compared to the basal B-50 level in nerves of control noncrushed rats.

\section{Time course of $B-50 \mathrm{mRNA}$ and $B-50$ protein content in DRG}

The time course of the change in B- 50 mRNA and B-50 protein in the ipsilateral DRG $\left(\mathrm{L}_{4} \mathrm{~L}_{5} \mathrm{~L}_{6}\right)$ in response to a crush lesion of the right sciatic nerve was determined over a period of 37 and $312 \mathrm{~d}$, respectively. B-50 mRNA levels were quantified from 2 series of Northern blots of total RNA from the ganglia of 2 rats (in duplicate), as described in Materials and Methods. The inset of Figure 3 shows the crucial time points from the 2 series. B- 50 and GAPDH probes showed specific hybridization with one band at positions 1.5 and $1.3 \mathrm{~kb}$, respectively, and little or no hybridization with the rRNAs.

The B-50 protein levels were determined by RIA. The amount of B-50 mRNA and B-50 protein in DRG was expressed as percentage of the value in noncrushed rats (approximately 15 ng B- $50 / \mathrm{mg}$ protein $=100 \%$, Fig. 3).

An initial rise in B-50 mRNA was detected $16 \mathrm{hr}$ after the lesion. B-50 mRNA content showed a linear and 10-fold increase till $48 \mathrm{hr}$ after crush. Subsequently, the level decreased gradually until it returned to control value at postoperation day 37 (Fig. 3). The first significant increase in B-50 protein was apparent $40 \mathrm{hr}$ after the crush lesion. The highest levels were observed between days 6 and 14. Levels of B-50 protein remained significantly higher in DRG of crushed rats compared to noncrushed, age-matched controls up to $61 \mathrm{~d}$. At 3.5 or 10 months after the crush, no difference in DRG B-50 levels between crushed and age-matched controls was found (Fig. 3).

\section{Effect of Org.2766 treatment or conditioning lesion on B-50 protein in $D R G$}

The amount of B-50 protein in DRG was significantly increased at days 2, 4, and 6 after crush in both saline- and Org.2766treated animals compared to noncrushed controls. There was no significant difference between saline- and peptide-treated rats (Fig. 4A). As can be seen in Figure 4B, B-50 levels in DRG of the conditioning lesion group were significantly different from the noncrushed controls (100\%) at all time points (days $0-6 ; p$ $<0.05$ ). The starting value at day 0 in the conditioning lesion group was already elevated (as day 0 after the test lesion is in 


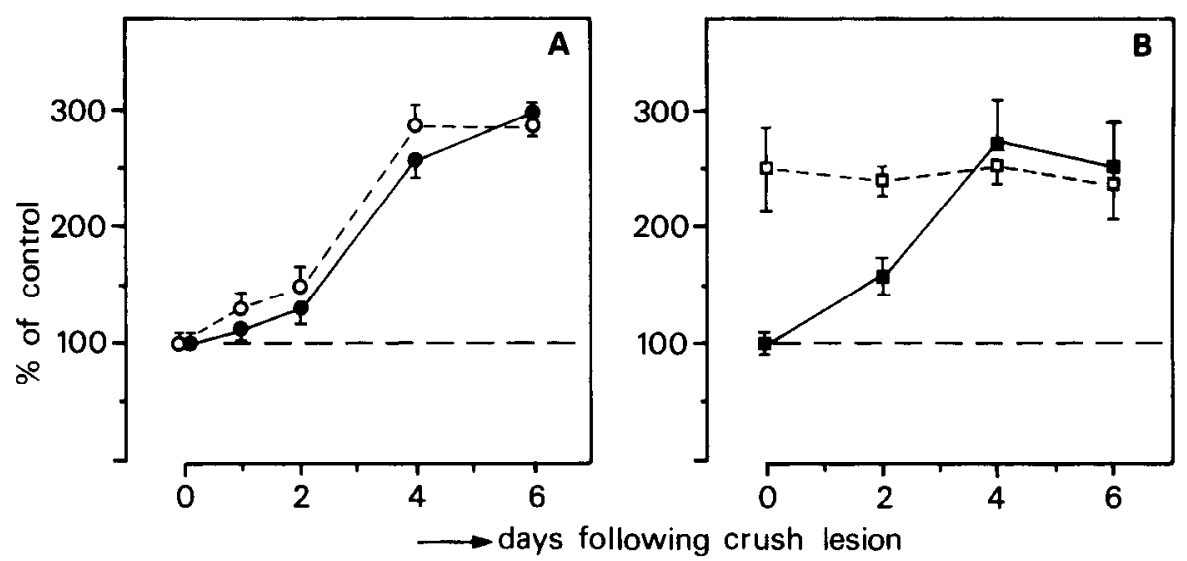

Figure 4. Effect of Org.2766 treatment $(A)$ or conditioning lesion $(B)$ on B-50 protein in DRG following crush lesion of the sciatic nerve. The B50 protein content in DRG was expressed as percentage of noncrushed rats $(100 \%=15 \mathrm{ng} / \mathrm{mg}$ protein). $A$, Rats were injected with either saline (O) or Org. $2766(7.5 \mu \mathrm{g} / \mathrm{kg} \mathrm{s.c.} / 48 \mathrm{hr})(0)$, starting immediately after the crush lesion. Values of both groups were significantly different from control level at day $2(p<0.05)$ and at days 4 and $6(p<0.01)$. No significant difference between the two treatments was found. $B$, Rats received a conditioning lesion 2 weeks before the test lesion $(\square)$ or received the test lesion only $(\square)$. Values of the conditioning lesion group were significantly different from the $100 \%$ level at all time points $(p<0.05)$. Values of the group with the test lesion only were significantly different from control level at days 2,4 , and $6(p<0.05)$. At day 0 and day 2 , a significant difference was observed between those two groups $(p<0.05)$. The significance of difference was determined with the Student's $t$ test.

fact day 14 of the prior conditioning lesion; see also Fig. 3) compared to the control level. Again, values of the group with the test lesion only were significantly different from control level at day 2,4 , and $6(p<0.05)$. At day 0 and day 2 , a significant difference was observed between conditioning and test lesion groups $(p<0.05)$. In a control experiment in noncrushed rats, no effect of saline or Org. $2766(7.5 \mu \mathrm{g} / \mathrm{kg} \mathrm{s.c.} / 48 \mathrm{hr})$ injections on the B-50 levels in DRG were observed (data not shown).

\section{Discussion}

The sciatic nerve crush model as described by De Koning et al. (1986) and used in the present study is suitable to monitor axonal regeneration in the rat peripheral nervous system. First signs of recovery of sensorimotor function of the hindpaw bearing the crush lesion as measured with the foot reflex withdrawal test usually can be observed around day 15 or 16 , whereas full recovery according to this test criterion is observed at approximately $21 \mathrm{~d}$ (Van der Zee et al., 1988). Treatment with Org.2766 during the regeneration period resulted in a significant accelerated recovery of sensorimotor function from day 17 on (Table $1 A$ ). These findings confirm previous work demonstrating a beneficial effect of melanocortins on nerve regeneration (Strand and Kung, 1980; Bijlsma ct al., 1981; De Koning et al., 1986; Dekker et al., 1987; Gispen et al., 1987; Verhaagen et al., 1987; Van der Zee et al., 1988). Melanocortins enhance nerve repair by increasing the number of outgrowing myelinated and unmyelinated sprouts (Bijlsma et al., 1983; Verhaagen et al., 1987). At the distal border of the crush lesion, the number of sprouts in Org.2766-treated rats was significantly increased from day 2 on, when the first sprouts appeared (Fig. 1). The difference between saline and Org.2766 treatment remained constant from the earliest measurement, indicating a fixed number of extra sprouts in the Org.2766-treated group (Fig. 1). This is in agreement with Verhaagen et al. (1987), who suggested that the number of sprouts rather than their growth rate is enhanced by peptide treatment.

A comparable enhancement of recovery of sensorimotor function after crush, ascertained with the foot reflex withdrawal test, was observed in rats receiving a conditioning lesion 2 weeks before the test lesion (Table $1 B$ ). These results are in agreement with those of McQuarrie et al. (1977), McQuarrie (1979), and Carlsen (1983). According to these authors, conditioning lesioning resulted in a reduced delay before outgrowth of newly formed sprouts. They also reported an accelerated outgrowth rate, measuring the front of the fastest growing sensory axons, determined from the response of the rat to pinching the skin with a forceps. Morphological evidence for enhanced growth following conditioning lesion is provided by McQuarrie (1985). At $9 \mathrm{hr}$ after a sciatic nerve crush, there is a $24 \%$ increase in cytoskeleton containing sprouts at $200-500 \mu \mathrm{m}$ proximal to the crush when the tibial nerve had been transected $14 \mathrm{~d}$ previously.

Several years ago, metabolic labeling studies demonstrated that the expression of some proteins, later defined as GAPs, is greatly enhanced during axonal regeneration (Skene and Willard, 1981; Benowitz and Lewis, 1983). More recently, molecular cloning of one of these proteins, designated as GAP43 (Basi et al., 1987; Karns et al., 1987; Neve et al., 1987), F1 (Rosenthal et al., 1987), B-50 (Nielander et al., 1987), and P57 (Cimler et al., 1987), makes it possible to study the expression of this protein at the mRNA level, in combination with measurements of the actual protein level.

Previous studies measuring RIA levels of B-50 around the crush site $6 \mathrm{~d}$ after the lesion showed marked increase in B-50 protein levels at the site and distally of the crush (Verhaagen et al., 1986). We estimated from immunofluorescence studies (Verhaagen et al., 1987) that at this time point, newly formed sprouts will have reached a length of approximately $15 \mathrm{~mm}$ distally. In the present study, RIA was used to measure B-50 levels distal to the crush site at day 6 after the lesion (Fig. 2). In segment IV, where at this time point no newly formed sprouts will have arrived, contained similar amounts of B-50 protein as the values measured in noncrushed control rats. This may correspond to the immunoreactivity detected in previous immunofluorescence studies. A relatively slow breakdown of B-50 was observed after transection of the sciatic nerve in the degenerating neuromuscular junction (Verhaagen et al., 1988) and 
after a unilateral mesencephalic lesion (Oestrcicher ct al., 1988). The increase in the amount of B-50 in the first 2 distal nerve segments (a distance of $10 \mathrm{~mm}$ ) correlates well with the number of newly formed sprouts in these segments (Figs. 1, 2A; Verhaagen et al., 1987). The increased B-50 level in rat peripheral nerve $6 \mathrm{~d}$ after a crush lesion is consistent with the results of metabolic labeling studies of GAP43/GAP48 (Skene and Willard, 1981; Benowitz and Lewis, 1983; Kalil and Skene, 1986) and with data obtained by RIA from Verhaagen et al. (1986). Similarly, Tetzlaff et al. (1989), studying axonal transport and localization of B-50/GAP43-like immunoreactivity in the regenerating sciatic nerve, observed that the greatest increase of B-50 resided in the newly regenerated portion of the nerve.

Treatment with Org. 2766 (Fig. $2 A$ ) or a conditioning lesion (Fig. $2 B$ ) further enhanced the increase in the amount of B-50 protein. Moreover, Org.2766-treated rats showed a significant increase in the B-50 protein amount in segment III, whereas in saline-treated animals, the B-50 content was not different from that of noncrushed rats. These data support those presented in Figure 1, indicating that after Org. 2766 treatment, more sprouts have grown further into the nerve. Bisby and Zwiers (1989) did not find a further increase in GAP/B-50 from a conditioning lesion. However, they studied metabolic labeling of the protein, whereas we determined the levels by RIA. We deduce from these data that the B-50 protein content is correlated proportionally with the number of sprouts. Therefore, the enlarged increase in B-50 content as a result of a conditioning lesion or treatment with Org. 2766 is most likely a reflection of the increase in the number of sprouts.

The effects of peptide treatment or conditioning lesioning on B-50 protein levels were also studied in DRG $\left(\mathrm{L}_{4} \mathrm{~L}_{5} \mathrm{~L}_{6}\right)$ containing the cell bodies of the sensory neurites in the rat sciatic nerve (Fig. 4). Interestingly, treatment with the peptide did not result in a further increase in DRG B-50 content, whereas in animals so treated, more $\mathrm{B}-50$ was observed in the regenerating nerve. The absence of effect on B-50 levels in DRG could be interpreted such that apparently the peptide preferentially stimulates outgrowth of motor axons derived from cell bodies in the spinal cord. However, there is ample evidence indicating that peptide treatment affects both motor and sensory neuronal regeneration and neurite outgrowth (De Koning et al., 1986; Gerritsen van der Hoop et al., 1988). Apparently, the DRG cell bodies contain sufficient B-50 to support the peptide-stimulated increase in number of outgrowing sprouts. The extra sprouts and elevated B-50 protein levels in the nerve, as a result of the Org. 2766 treatment, imply an enlarged axonal transport of the B-50 protein. In contrast, the conditioning lesion resulted in an increase in B-50 levels in both DRG cell bodies and sciatic nerve shortly after the test lesion (Figs. 2B, 4B). However, the situation in the DRG cell bodies at day 0 following the test lesion is comparable to day 14 following a single crush lesion (see Fig. 3), when an enhanced B-50 level is observed. Placement of the test lesion did not further elevate this level. It may be that the high levels of B-50 in the DRG at the time of placement of the test lesion, as reported here, are part of the molecular basis underlying the known shortening of delay in sprouting following the second test crush (McQuarrie et al., 1977; McQuarrie, 1978). Dekker (1987) concluded that there is a common step in the mechanism of action of the conditioning lesion effect and that of peptide treatment on rat sciatic nerve regeneration. Apparently, that step is not the amount of B-50 present in the DRG cell body during regeneration.
In the present study of the crush lesion in rat sciatic nerve, we also monitored B-50 expression at the level of mRNA in the neuronal cell bodies in the DRG (Fig. 3). The specific hybridization signal of a B-50 cRNA probe with one mRNA band $(1.5 \mathrm{~kb})$ was quantified by image analysis and compared with the specific GAPDH cDNA-hybridization signal (1.3 kb) (Fig. 3 , inset). Between 8 and $16 \mathrm{hr}$ after placement of the crush lesion, a rise in B-50 mRNA level became already apparent. A linear increase up to 10 times the basal level of B-50 mRNA up to $2 \mathrm{~d}$ postsurgery was observed. This was followed by an initial rapid, later slower decrease (Fig. 3). Return to the level of noncrushed rats was not apparent until day 37 . A rise in mRNA of one order of magnitude in DRG following crush was reported previously, for one time point, i.e., $14 \mathrm{~d}$ postsurgery (Basi et al., 1987). Under our conditions, such a dramatic change was already apparent at day 2 after crush. The level of B-50 mRNA at day 14 is only about 3 times elevated (Fig. 3). Such variations, however, might be explained by differences in experimental procedures, such as the position and the nature of the crush lesion and the strain and the age of the rats.

The expression of GAP43 and B-50 mRNA and protein in rat CNS is highest during synaptogenesis in the first week after birth (Jacobson et al., 1986; Basi et al., 1987; Karns et al., 1987; Nielander et al., 1987; Zwiers et al., 1987). It has been postulated from the existence of one single GAP43 gene and concomitant changes in the levels of the protein and the mRNA in the developing CNS that the main regulation of the expression of GAP43 is at the transcriptional level (Basi et al., 1987).

In the DRG of the regenerating sciatic nerve, the kinetics of B-50 mRNA expression are similar to those described for GAP43 during CNS development (Basi et al., 1987). Protein levels, however, followed the increase of mRNA with some delay. The first significant rise was measured $40 \mathrm{hr}$ after crush, and a maximum level was attained between 6 and $20 \mathrm{~d}$. However, the relative increase in B-50 protein level is lower (3 times) than that observed in B-50 mRNA, and the time curve is more smooth. Differences in levels may be accounted for by the fact that mRNA remains in the cell bodies, whereas the B-50 protein is rapidly transported into the axons (Skene and Willard, 1981; Kalil and Skene, 1986; Bisby and Zwiers, 1989).

The slower initial kinetics of the protein levels might relate to the time needed for translation of the mRNA into protein and for processing and transport of the protein (Watson et al., 1987). Furthermore, sustained elevation of B-50 protein level was observed in DRG cell bodies till about $61 \mathrm{~d}$ after crush. This is much longer than the elevation of B-50 mRNA in these DRG. These data suggest that the expression of B-50 in DRGs after a crush lesion of the sciatic nerve is regulated not only by mRNA transcription but also by factors that influence the protein half-life.

In this paper we have presented evidence that in the crush model of the rat sciatic nerve, the regenerative response is correlated, in the cell bodies of $\mathrm{DRG}$, with enhanced expression of B-50 mRNA and B-50 protein and, in the extending nerve, with enhanced B-50 levels, reflecting the outgrowing number of sprouts. The enhanced expression of the growth-associated protein B-50 seems rather specific for this class of proteins (Skene and Willard, 1981). In previous studies (Edwards et al., 1985) using SDS-PAGE, no significant increases in protein bands were detected in distal nerve segments at $4 \mathrm{~d}$ after the crush lesion. In this study, expression of the mRNA of GAPDH, one of the glycolytic enzymes, did not change significantly. Furthermore, 
a first indication was obtained that the enhancement of nerve regeneration and sprouting following a conditioning lesion or Org. 2766 treatment might involve B-50 expression as well. The latter statement, however, awaits support from studies on mRNA levels at the level of the cell bodies.

\section{References}

Aloyo, V. J., H. Zwiers, and W. H. Gispen (1983) Phosphorylation of B-50 protein by calcium-activated, phospholipid-dependent protein kinase and B-50 protein kinase. J. Neurochem. 41: 649-653.

Amasino, R. M. (1986) Acceleration of nucleic acid hybridization rate by polyethylene glycol. Anal. Biochem. 152: 304-307.

Basi, G. S., R. D. Jacobson, I. Virag, J. Schilling, and J. H. P. Skene (1987) Primary structure and transcriptional regulation of GAP43, a protein associated with nerve growth. Cell 49: 785-791.

Benowitz, L. I., V. E. Shashoua, and M. Yoon (1981) Specific changes in rapidly transported proteins during regeneration of the goldfish optic nerve. J. Neurosci. 1: 300-307.

Benowitz, L. I., and E. R. Lewis (1983) Increased transport of 4449,000 dalton acidic proteins during regeneration of the goldfish optic nerve: A 2-dimensional gel analysis. J. Neurosci. 3: 2153-2163.

Bijlsma, W. A., F. G. I. Jennekens, P. Schotman, and W. H. Gispen (1981) Effects of corticotrophin (ACTH) on recovery of sensorimotor function in the rat: Structure-activity study. Eur. J. Pharmacol. 76: 73-79.

Bijlsma, W. A., F. G. I. Jennekens, P. Schotman, and W. H. Gispen (1983) Stimulation by ACTH(4-10) of nerve fiber regeneration following sciatic nerve crush. Muscle Nerve 6: 104-112.

Bisby, M. A., and H. Zwiers (1989) Localization of B-50, a synaptic phosphoprotein, in regenerating rat sciatic nerves. Can. J. Physiol. Pharmacol. (in press).

Carlsen, R. C. (1983) Delayed induction of the cell body response and enhancement of regeneration following a conditioning test lesion of frog peripheral nerve at $15^{\circ} \mathrm{C}$. Brain Res. 279: 9-18.

Chirgwin, J. M., A. E. Pryzbala, R. J. MacDonald, and W. J. Rutter (1979) Isolation of biologically active ribonucleic acid from sources enriched in ribonuclease. Biochemistry 18: 5294-5299.

Cimler, B. M., D. H. Giebelhaus, B. T. Wakim, D. R. Storm, and R. $T$. Moon (1987) Characterization of murine cDNAs encoding P-57, a neural-specific calmodulin-binding protein. J. Biol. Chem. 262: $12158-12163$

De Graan, P. N. E., C. O. M. Van Hooff, B. C. Tilly, A. B. Oestreicher, P. Schotman, and W. H. Gispen (1985) Phosphoprotein B-50 in nerve growth concs from fetal rat brain. Neurosci. Lett. 61: 235-241.

Dekker, A. J. A. M. (1987) Enhancement of peripheral nerve regeneration in the rat by a previous nerve injury and by treatment with neuropeptides. Ph.D. Thesis, University of Utrecht, NL.

Dekker, A. J. A. M., M. M. Princen, H. de Nijs, L. G. J. de Leede, and C. L. E. Broekkamp (1987) Acceleration of recovery from sciatic nerve damage by the ACTH-(4-9) analog Org.2766: Different routes of administration. Peptides 8: 1657-1659.

De Koning, P., J. H. Brakkee, and W. H. Gispen (1986) Methods for placing a reproducible crush in the sciatic and tibial nerve of the rat and rapid and precise testing of return of sensory function: Beneficial cffccts of mclanocortins. J. Ncurol. Sci. 74: 237-256.

DeLeon, D. V., K. H. Cox, L. M. Angerer, and R. C. Angerer (1983) Most early-variant histone mRNA is contained in the pronucleus of sea urchin eggs. Dev. Biol. 100: 197-206.

Edwards, P. M., J. Verhaagen, T. Spierings, P. Schotman, F. G. I. Jennekens, and W. H. Gispen (1985) The effect of ACTH(4-10) on protein synthesis, actin and tubulin during regeneration. Brain Res. Bull. 15: 267-272.

Gerritsen van der Hoop, R., P. De Koning, E. Boven, J. P. Neijt, F. G. I. Jennekens, and W. H. Gispen (1988) Efficacy of the neuropeptide Org.2766 in the prevention and treatment of cisplatin-induced neurotoxicity in rats. Eur. J. Cancer Clin. Oncol. 24: 637-642.

Gispen, W. H., P. N. E. De Graan, S. Y. Chan, and A. Routtenberg (1986) Comparison between the neural acidic proteins B-50 and F1. Prog. Brain Res. 69: 383-385.

Gispen, W. H., P. De Koning, R. R. F. Kuiters, C. E. E. M. Van der Zee, and J. Verhaagen (1987) On the neurotrophic properties of melanocortins. Prog. Brain Res. 72:319-331.

Glisin, V., A. Crkvenjakov, and C. Byus (1974) Ribonucleic acid isolated by cesium chloride centrifugation. Biochemistry 13: 26332637.

Gorgels, Th. G. M. F., A. B. Oestreicher, E. J. M. De Kort, and W. H. Gispen (1987) Immunocytochemical distribution of the protein kinase $\mathrm{C}$ substrate $\mathrm{B}-50$ (GAP43) in developing rat pyramidal tract. Neurosci. Lett. 83: 59-64.

Jacobson, R. D., I. Virag, and J. H. P. Skene (1986) A protein associated with axon growth, GAP43, is widely distributed and developmentally regulated in rat CNS. J. Neurosci. 6: 1843-1855.

Kalil, K., and J. H. P. Skene (1986) Elevated synthesis of an axonally transported protein correlates with axon outgrowth in normal and injured pyramidal tracts. J. Neurosci. 6: 2563-2570.

Karns, L. R., S. C. Ng, J. A. Freeman, and M. C. Fishman (1987) Cloning of complementary DNA for GAP43, a neuronal growthrelated protein. Science 236: 597-600.

Katz, F., L. Ellis, and K. H. Pfenninger (1985) Nerve growth cones isolated from fetal rat brain. III. Calcium-dependent phosphorylation. J. Neurosci. 5: 1402-1411.

Lowry, O. H., N. J. Rosebrough, A. L. Farr, and R. J. Randall (195l) Protein measurement with the Folin phenol reagent. J. Biol. Chem. 193: 265-275.

Maniatis, T., E. F. Firitsch, and J. Sambrook, eds. (1982) Molecular Cloning: A Laboratory Manual, Cold Spring Harbor Lab, Cold Spring Harbor, NY.

McLean, I. W., and P. K. Nakane (1977) Periodate-lysinepara-formaldehyde fixative: A new fixative for immunoelectron microscopy. J. Histochem. Cytochem. 22: 1077-1083.

McMaster, G. K., and G. G. Carmichael (1977) Analysis of singleand double-stranded nucleic acids on polyacrylamide and agarose gels by using glyoxal and acridine orange. Proc. Natl. Acad. Sci. USA 74: 4835-4838.

McQuarrie, I. G. (1978) The effect of a conditioning lesion on the regeneration of motor axons. Brain Res. 152: 597-602.

McQuarrie, I. G. (1979) Accelerated axonal sprouting after nerve transection. Brain Res. 167: 185-188.

McQuarrie, I. G. (1985) Effect of a conditioning lesion on axonal sprout formation at nodes of Ranvier. J. Comp. Neurol. 231: 239249.

McQuarrie, I. G., and B. Grafstein (1973) Axon outgrowth enhanced by a previous nerve injury. Arch. Neurol. 29: 53-55.

McQuarrie, I. G., B. Grafstein, and M. D. Gershon (1977) Axonal regeneration in the rat sciatic nerve: Effect of a conditioning lesion and of dBcAMP. Brain Res. 132: 443-453.

Meiri, K., K. Pfenninger, and M. Willard (1986) Growth-associated protein, GAP43, a polypeptide that is induced when neurons extend axons, is a component of growth cones and corresponds to a major polypeptide enriched in growth cones. Proc. Natl. Acad. Sci. USA 83: 3537-3541.

Neve, R. L., N. I. Perrone-Bizzozero, S. Finklestein, H. Zwicrs, E. Bird, D. M. Kurmit, and L. I. Benowitz (1987) The neuronal growthassociated protein GAP43 (B-50, F1): Neuronal specificity, developmental regulation and regional distribution of the human and rat mRNAs. Mol. Brain Res. 2: 177-183.

Nielander, H. B., L. H. Schrama, A. J. Van Rozen, M. Kasperaitis, A. B. Oestreicher, P. N. E. De Graan, W. H. Gispen, and P. Schotman (1987) Primary structure of the neuron-specific phosphoprotein B-50 is identical to growth-associated protein GAP-43. Neurosci. Res. Commun. 1 : 163-172.

Oestreicher, A. B., C. J. Van Dongen, H. Zwiers, and W. H. Gispen (1983) Affinity-purified anti-B-50 protein antibody: Interference with the function of the phosphoprotein B-50 in synaptic plasma membranes. J. Neurochem. 41: 331-340.

Oestreicher, A. B., L. V. Dckker, and W. H. Gispen (1986) A radioimmunoassay for the phosphoprotein B-50: Distribution in rat brain. J. Neurochem. 46: 1366-1369.

Oestreicher, A. B., and W. H. Gispen (1986) Comparison of the immunocytochemical distribution of the phosphoprotein B-50 in the cerebellum and hippocampus of immature and adult rat. Brain Res. 375: 267-279.

Oestreicher, A. B., P. Devay, R. L. Isaacson, and W. H. Gispen (1988) Changes in the distribution of the neuron-specific B-50, neurofilament protein and glial fibrillary acidic proteins following an unilateral mesencephalic lesion in the rat. Brain Res. Bull. 21: 713-722.

Perrone-Bizzozero, N. I., S. P. Finklestein, and L. I. Benowitz. (1986) Synthesis of a growth-associated protein by embryonic rat cerebrocortical neurons in vitro. J. Neurosci. 6: 3721-3730. 
Pfenninger, K. H. (1986) Of nerve growth cones, leukocytes and memory: Second messenger systems and growth-regulated proteins. Trends Neurosci. 9: 562-564.

Rosenthal, A., S. Y. Chan, W. Henzel, C. Haskell, W.-J. Kuang, E. Chen, J. N. Wilcox, A. Ullrich, D. V. Goeddel, and A. Routtenberg (1987) Primary structure and mRNA localization of protein F1, a growth-related protein kinase $C$ substrate associated with synaptic plasticity. EMBO J. 6: 3641-3646.

Skene, J. H. P., and M. Willard (1981) Changes in axonally transported proteins during regeneration in toad retinal ganglion cells. J. Cell Biol. 89: 86-95.

Skene, J. H. P., R. D. Jacobson, W. J. Snipes, C. B. McGuire, J. J. Norden, and J. A. Freeman (1986) A protein induced during nerve growth (GAP43) is a major component of growth-cone membranes. Science 233: 763-768.

Strand, F. L., and T. T. Kung (1980) ACTH accelerates recovery of neuromuscular function following crushing of peripheral nerve. Peptides $1: 135-138$.

Tetzlaff, W., H. Zwiers, K. Lederis, L. Cassar, and M. A. Bisby (1989) The axonal transport and localization of B-50/GAP43-like immunoreactivity in regenerating sciatic and facial nerves of the rat. $J$. Neurosci. 9: 1303-1313.

Van der Zee, C. E. E. M., J. H. Brakkee, and W. H. Gispen (1988) $\alpha$-MSH and Org. 2766 in peripheral nerve regeneration: Different routes of delivery. Eur. J. Pharmacol. 147: 351-357.

Van Hooff, C. O. M., P. N. E. De Graan, J. Boonstra, A. B. Oestreicher, M. H. Schmidt-Michels, and W. H. Gispen (1986) Nerve growth factor enhances the level of the protein kinase C substrate B-50 in pheochromocytoma PC12 cells. Biochem. Biophys. Res. Commun. 139: 644-651.

Van Hooff, C. O. M., P. N. E. De Graan, A. B. Oestreicher, and W. H. Gispen (1988) B-50 phosphorylation and polyphosphoinositide metabolism in nerve growth cone membranes. J. Neurosci. 8: 17891795.

Verhaagen, J., C. O. M. Van Hooff, P. M. Edwards, P. N. E. De Graan, A. B. Oestreicher, F. G. I. Jennekens, and W. H. Gispen (1986) The kinase $C$ substrate protein B-50 and axonal regeneration. Brain Res. Bull. 17: 737-741.

Verhaagen, J., P. M. Edwards, F. G. I. Jennekens, and W. H. Gispen (1987) Pharmacological aspects of the influence of melanocortins on the formation of regenerative peripheral nerve sprouts. Peptides 8: $581-584$.

Verhaagen, J., A. B. Oestreicher, P. M. Edwards, H. Veldman, F. G. I. Jennekens, and W. H. Gispen (1988) Light and electron microscopical study of phosphoprotein B-50 following denervation and reinnervation of the rat soleus muscle. J. Neurosci. 8: 1759-1766.

Watson, J. D., N. H. Hopkins, J. W. Roberts, J. A. Steitz, and A. M. Weiner, eds. (1987) The Molecular Biology of the Gene, 4th ed., Vol. 1, pp. 722-723.

Zwiers, H., A. B. Oestreicher, M. A. Bisby, P. N. E. De Graan, and W. H. Gispen (1987) Protein kinase C substrate B-50 in adult and developing rat brain is identical to axonally transported GAP-43 in regenerating peripheral rat nerve. In Axonal Transporl, R. A. Smith and M. Bisby, eds., pp. 421-433, Liss, New York. 